\title{
An update on the physiology of two- and three-toed sloths
}

D.P. Gilmore²,

C.P. Da-Costa ${ }^{1}$ and

D.P.F. Duarte ${ }^{1}$

\author{
${ }^{1}$ Departamento de Fisiologia e Farmacologia, \\ Universidade Federal de Pernambuco, Recife, PE, Brasil \\ 2Institute of Biomedical and Life Sciences, University of Glasgow, \\ Glasgow, UK
}

\section{Correspondence \\ C.P. Da-Costa \\ Departamento de Fisiologia e \\ Farmacologia, UFPE \\ 50670-901 Recife, PE \\ Brasil \\ Fax: +55-81-271-8350 \\ E-mail: cpc@npd.ufpe.br \\ Research supported by $\mathrm{CNPq}$ and \\ FACEPE. D.P. Gilmore is the \\ recipient of a Royal Society \\ and Brazilian Academy of Sciences \\ international exchange \\ fellowship.}

Received March 31, 1999 Accepted October 14, 1999

\section{Abstract}

Physiological and pharmacological research undertaken on sloths during the past 30 years is comprehensively reviewed. This includes the numerous studies carried out upon the respiratory and cardiovascular systems, anesthesia, blood chemistry, neuromuscular responses, the brain and spinal cord, vision, sleeping and waking, water balance and kidney function and reproduction. Similarities and differences between the physiology of sloths and that of other mammals are discussed in detail.

\section{Introduction}

It is almost 30 years since Goffart (1) published Function and Form in the Sloth and in the time that has now elapsed there has been no further comprehensive evaluation of the biology of this mammal. It is the intention of the present review to bring together research reports of physiological and pharmacological studies that have appeared since 1971 and thereby update our knowledge about this intriguing animal.

Sloths are included, along with the armadillos and anteaters, in the Order Xenarthra (Edentata). Analysis of amino acid sequences of the eye lens proteins (2) has confirmed earlier anatomical evidence indicating that the xenarthrans are an old offshoot of the eutherian stem that arose at least 75-80 million years ago. Initially all present-day sloths were considered to belong to the family Bradypodidae with two genera, Bradypus and Choloepus. However, a new classifica- tion has been proposed (3), which places the two-toed sloths in the family Megalonychidae and the three-toed sloths in the family Bradypodidae. It is thus now generally believed that the two living families of sloths have quite different phylogenetic origins and that Bradypus is derived from megatheroid and Choloepus from megalonychid sloths, their separate evolution beginning about 35 million years ago in the late Oligocene.

The distribution of two- and three-toed sloths in South America is illustrated in Figures $1 \mathrm{~A}$ and B. Bradypus variegatus, the brown-throated three-toed sloth, is one of the most common medium-sized mammals in the tropical forests of Central and South America. Previously many workers have referred to the species as Bradypus tridactylus but this, the pale-throated three-toed sloth, is now regarded as the one found only in southern Venezuela, the Guianas and northern Brazil south to the Rio Amazonas. Throughout this review an attempt has been made to 
Figure 1 - Distribution of twoand three-toed sloths throughout Central and South America $(A, B)$ (for further details see Wetzel (3)). distinguish between the misnamed Bradypus tridactylus $=$ variegatus and the rightful bearer of the title.

All xenarthrans have low body temperatures compared to other mammals, ranging

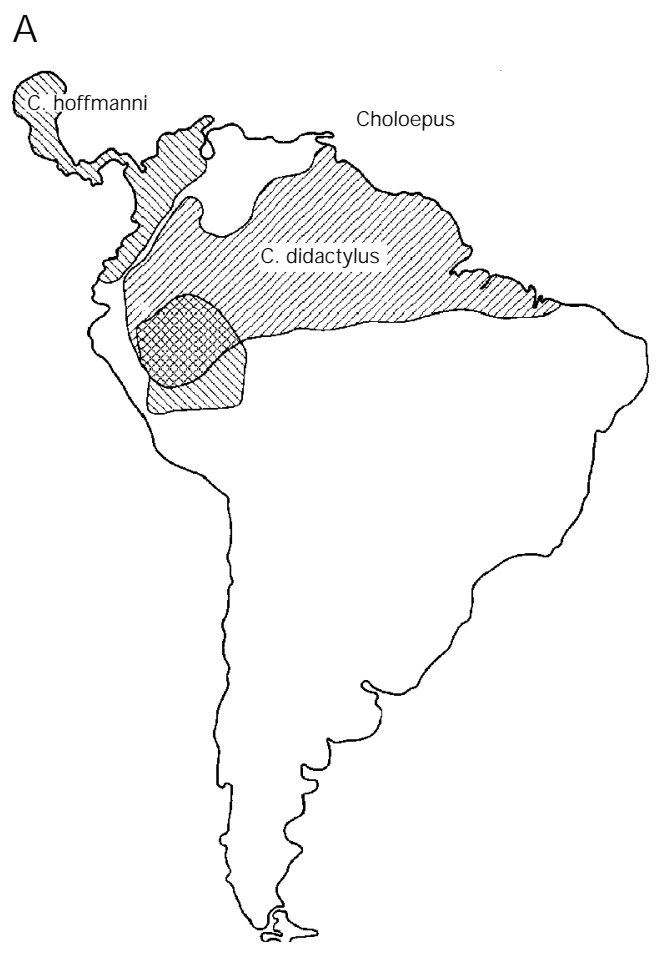

B

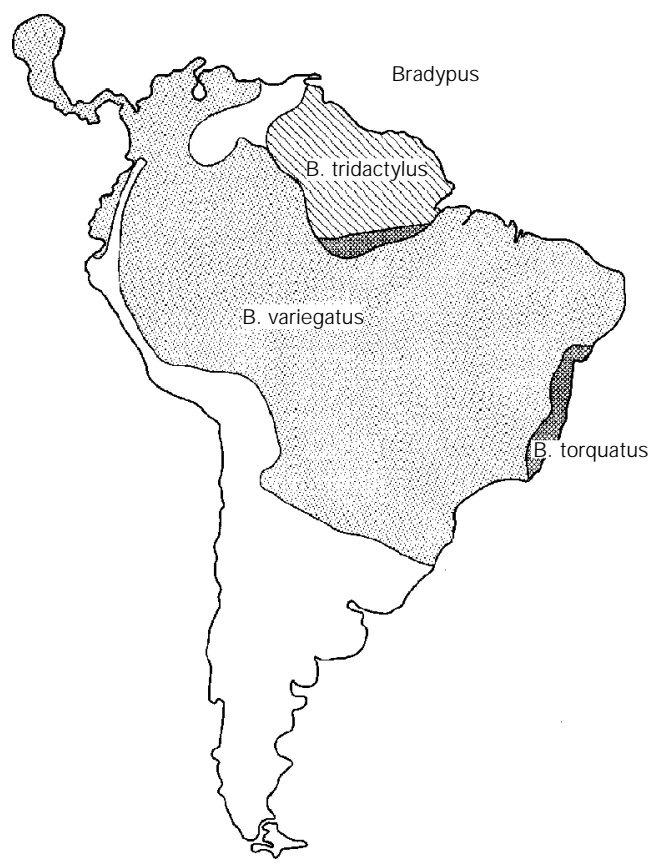

from $32.7^{\circ}$ to $35.5^{\circ} \mathrm{C}(4)$. In most, their basal metabolic rates lie between 40 and $60 \%$ of those expected from their mass on the basis of Kleiber's rule and in the case of the tree sloths may be directly related to the reduction in muscle mass correlated with their sedentary lifestyle (4). The type of food consumed would also appear to be influential in setting the low basal metabolic rates in xenarthrans for, firstly, the food of sloths has a low energy content and, secondly, it may contain poisonous compounds that require a low rate of absorption for adequate detoxification (4). The low body temperature of both Bradypus and Choloepus, which varies with that of their surroundings, is a major factor restricting their distribution. Goffart (1) discussed thermoregulation in the sloth in detail. More recently, Silva et al. (5) recorded rectal temperatures in five adult male sloths (Bradypus variegatus) at four-hour intervals over six days. They observed a circadian rhythm in body temperature (ranging from $28^{\circ}$ to $35^{\circ} \mathrm{C}$ ), which was closely correlated with changes in environmental temperature. In cold conditions sloths are poor regulators of body temperature because they have little ability to increase their metabolism due to their small muscle masses. Thus neither $\mathrm{Bra}$ dypus nor Choloepus are able to tolerate cool temperate latitudes. Bradypus has a lower thermal conductance than Choloepus because only the former has a dense woolly undercoat below the coarse guard hairs, and Bradypus also has a lower limit of thermoneutrality $\left(24^{\circ} \mathrm{C}\right)$ than does Choloepus $\left(18^{\circ} \mathrm{C}\right)$.

\section{Respiratory and cardiovascular systems}

The normal respiratory rate in Choloepus hoffmanni when sleeping has been reported to be 13 per minute (range 10-18), decreasing when the rectal temperature exceeded $37^{\circ} \mathrm{C}(6)$. In captive sloths, with an ambient temperature of $30^{\circ} \mathrm{C}$, the respiratory rate was 
found to be dependent upon the animal's state. Excited or agitated sloths have been noted to breathe at a rate of between 10 and 30 per minute (7). In awake, but inactive, sloths in captivity the breathing rate was found to be 46 (range 38-52) breaths per minute (6) and in awake and active animals it was 73 (range 65-78). For both free-roaming and captive sloths in Panama, a resting rate of nine breaths per minute (range 8-11) has been reported (6). Respiration and heart rates in anesthetized two-toed sloths (Choloepus didactylus) were 18-48 breaths per minute and $48-108$ beats per minute (bpm), respectively (8). Félix et al. (9) carried out studies on the airway flow and pulmonary ventilation of Bradypus variegatus anesthetized with sodium pentobarbital, but breathing spontaneously. They reported that the tidal volume was $57.6 \pm 14.4 \mathrm{ml}$, the inspiration time $3.8 \pm 0.4 \mathrm{~s}$ and the expiration time $15.9 \pm 0.7 \mathrm{~s}$ for a respiratory rate of $3.0 \pm 0.8$ breaths per minute. Respiratory minute volume was $181.3 \pm 27.9 \mathrm{ml}$ and the expiratory pause $13.1 \pm 6.8 \mathrm{~s}$. This long respiratory pause observed in the anesthetized animal was also noted by Santos et al. (10), who monitored the breathing of four freely moving sloths (Bradypus variegatus) in the laboratory using an impedance technique. These animals were kept at a constant room temperature of $26^{\circ} \mathrm{C}$ for a period of $24 \mathrm{~h}$ in a $12-$ $\mathrm{h}$ light/12-h dark cycle. The respiratory rate was $8.6 \pm 5.3$ breaths per minute (range 4.920.6). Breathing was slowest at $11.30 \mathrm{~h}$ and most rapid at $2.30 \mathrm{~h}$ when there was an associated increase in the animals' motor activity. In other data obtained recently (11), over a 2 -h period from freely roaming sloths in the laboratory at $26^{\circ} \mathrm{C}$, the respiratory rate was found to be $6.1 \pm 0.81$ breaths per minute and the expiratory part of the cycle $71 \%$.

Aguiar et al. (12) also determined pulmonary volume and capacity in eight three-toed sloths (Bradypus variegatus) under sodium pentobarbital anesthesia. They reported the following values in relation to total lung capacity: tidal volume $13.5 \pm 3.4 \%$, inspiratory reserve volume $52.6 \pm 8.9 \%$, expiratory reserve volume $9.7 \pm 4.7 \%$, residual volume $24.2 \pm 6.8 \%$. Inspiratory capacity was $66.1 \pm$ $6.6 \%$, vital capacity $75.8 \pm 6.8 \%$ and functional residual capacity $33.9 \pm 6.6 \%$. In another study (13) the same group analyzed the active mechanical properties of these animals' lungs and recorded the following: (mean $\pm \mathrm{SD}$ ) $0.33 \pm 0.10 \mathrm{cmH}_{2} \mathrm{O} / 1$ and 0.09 $\pm 0.02 \mathrm{cmH}_{2} \mathrm{O} / 1$ for resistance and active elasticity of the respiratory system. Other research (14) into the passive mechanical properties of the lung and thoracic wall in three-toed sloths (Bradypus variegatus) recorded the following values (mean $\pm \mathrm{SD}$ ) of $0.183 \pm 0.030 \mathrm{cmH}_{2} \mathrm{O} / \mathrm{ml}$ for passive elasticity of the respiratory system, $0.045 \pm 0.002$ $\mathrm{cmH}_{2} \mathrm{O} / \mathrm{ml}$ for passive elasticity of the pulmonary system and $0.134 \pm 0.024 \mathrm{cmH}_{2} \mathrm{O} /$ $\mathrm{ml}$ for the thoracic wall, respectively. Active elasticity and active resistance were found to be 13 and $56 \%$ higher, respectively, than the passive counterparts.

The size of the heart is adapted to the quiet life of the sloth, but it is by no means responsible for the inability of these animals to undertake sustained speedy movement. The heart rate of Bradypus was initially reported (7) to range from 60 to $110 \mathrm{bpm}$, with that of Choloepus being somewhat higher (70-130 bpm). A great deal more information has since been obtained on cardiovascular function in the sloth, mainly from the group working at the Federal University of Pernambuco in Recife. Research there (15, 16) on Bradypus tridactylus = variegatus, under pentobarbital anesthesia, found heart rates of $91 \pm 4.5 \mathrm{bpm}$ and $94.1 \pm 3.3 \mathrm{bpm}$, respectively. Another study (17) demonstrated similar values $(91 \mathrm{bpm})$ in sloths under chloralose anesthesia. In conscious, but restrained cannulated sloths (Bradypus tridactylus $=$ variegatus $)$ heart rates of 89.7 $\pm 9.7 \mathrm{bpm}$ were measured (16). When the animals were positioned in an experimental chair similar values were recorded (18). In 
contrast, these same animals prior to surgical manipulation presented heart rates of $71.8 \pm 15.9 \mathrm{bpm}$ when in the erect posture in the experimental chair.

There is a popular impression that sloths spend a large part of their time suspended from tree branches hanging upside down. However, Duarte et al. (18) observed that three-toed sloths (Bradypus variegatus), when left free to roam in the laboratory, spent much of their time seated with the hind limbs wrapped around any vertical object available and with the head down upon the chest. The forelimbs might or might not be encircling the upright object. These same workers found that in unrestrained conditions the sloths' heart rates were $76 \pm 20.8$ in the sitting position and $79.8 \pm 22.3$ in the suspended one. On the other hand, when these animals were placed in an experimental chair in the supine posture (similar to when suspended in unrestrained conditions) their heart rates were lower $(79.8 \pm 10.7)$ compared to those recorded under erect conditions (similar to when seated in unrestrained conditions) which were $87.4 \pm 12 \mathrm{bpm}$. In non-surgically manipulated sloths these values were maintained $(71.8 \pm 15.9$ in erect versus $66.2 \pm 17.8$ in supine), showing that the posture adopted by these animals in the laboratory interferes with the levels of heart rate and indicates that they are under stress after surgical manipulation.

Other research (19) on the autonomic component in the heart rate of Bradypus tridactylus $=$ variegatus demonstrated that atropine raised the heart rate from $83.3 \pm$ 10.8 to $96.5 \pm 8.6 \mathrm{bpm}$. Propranolol slowed the heart rate from $84.5 \pm 9.9$ to $65.5 \pm 5.96$ bpm. After double blockade in one order or vice versa, heart rate was $74.2 \pm 5.6 \mathrm{bpm}$, showing that in the animals under laboratory conditions there is a slight predominance of sympathetic tone at rest. The fact that atropine elevated heart rate by only $16 \%$ in the study suggests that there may be an upper limit to the rate at which the sloth's heart can be driven. This could be in the neighborhood of $110 \mathrm{bpm}$.

Biotelemetry has been used to monitor heart rate changes during a period of $24 \mathrm{~h}$ in sloths (Bradypus variegatus) allowed to roam freely in a laboratory (20). Mean heart rate values were $88 \pm 8 \mathrm{bpm}$, but these showed a biphasic variation pattern during the period of observation with the lower values (66 bpm) being observed during daylight $(9.00$ h). This variation was directly related to a decrease in motor activity seen in the animals at this time. The highest heart rate (108 bpm) was observed at $19.00 \mathrm{~h}$. When the ECG pattern was determined a sinus rhythm was present in all the records. For a mean heart rate of $81 \pm 18 \mathrm{bpm}$ the duration (in milliseconds) of the $\mathrm{P}$ wave was $49.18 \pm$ 15.57, of the PR segment 71.62 \pm 18.11 , of the QRS complex $70.45 \pm 21.64$, of the ST segment $113.93 \pm 48.46$, and of the $T$ wave $152.76 \pm 48.71$. These values for the various ECG components are near those obtained for other mammals of the same size. In the frontal plane the mean $\mathrm{P}$ axis was $+15^{\circ}\left(-60^{\circ}\right.$ to $\left.+90^{\circ}\right)$, the mean $\mathrm{QRS}$ axis was $-20^{\circ}\left(-100^{\circ}\right.$ to $\left.+60^{\circ}\right)$ and the $T$ axis was $0^{\circ}\left(-75^{\circ}\right.$ to $\left.+75^{\circ}\right)$, suggesting that the sloth heart lies in a semihorizontal position.

In a study (15) on cardiac mass, blood temperature and ventricular fibrillation in the three-toed sloth (Bradypus variegatus) comparisons were made with the domestic cat, the latter chosen for having approximately the same heart and body size. Sloth hearts were more difficult to fibrillate and once fibrillation was induced it interestingly recovered more quickly than did the heart of the cat in the same situation. When ventricular fibrillation thresholds were investigated in sloths (Bradypus tridactylus $=$ variegatus $)$ and puppies (21) by using a predetermined train of rectangular pulses the average ventricular fibrillation threshold current was 2.3 $\pm 0.4 \mathrm{~mA} / \mathrm{g}$ for the sloth heart and when fibrillation was induced $40 \%$ of the sloths showed a spontaneous reversal. The average 
ventricular fibrillation threshold current was $0.59 \pm 0.14 \mathrm{~mA} / \mathrm{g}$ for the puppy heart, corresponding to a significant 4-fold difference in threshold current between the two animals. In another comparative study of myocardial mechanical characteristics in the sloth (Bradypus tridactylus = variegatus), cat and rat (22) the time to peak tension was significantly higher in the sloth $(444 \pm 33.7 \mathrm{~ms})$ than in the cat $(327 \pm 21.5 \mathrm{~ms})$ and the rat $(119 \pm 9.1 \mathrm{~ms})$. The $\mathrm{df} / \mathrm{dt}$ maximum was also different in the three species, being $2.9 \pm 0.7$ $\mathrm{g} / \mathrm{s}$ in the sloth, $5.2 \pm 0.6 \mathrm{~g} / \mathrm{s}$ in the cat and 6.4 $\pm 0.8 \mathrm{~g} / \mathrm{s}$ in the rat. Not only the contractile process but also the relaxation process were slow in the sloth.

Cardiac output in the three-toed sloth has also been measured using a dye dilution technique (16). The values reported were $0.248 \pm 0.039 \mathrm{l} / \mathrm{min}$ for unanesthetized animals and $0.240 \pm 0.033 \mathrm{l} / \mathrm{min}$ for anesthetized animals. The cardiac index was $0.97 \pm$ $0.158 \mathrm{l} \mathrm{m}^{-2} \mathrm{~min}^{-1}$ in the unanesthetized sloth and $0.93 \pm 0.13 \mathrm{~m}^{-2} \mathrm{~min}^{-1}$ in the anesthetized sloth. Studies on blood pressure in the three-toed sloth cannulated under local anesthesia by the same authors found strikingly high values of $176.8 / 128.2 \mathrm{mmHg}$. These values fell substantially after the administration of pentobarbital anesthesia (15), suggesting that endogenous catecholamines might promote the apparent hypertension seen in the unanesthetized sloth. This view was supported by the work of Duarte et al. (23), who demonstrated that conscious sloths (Bradypus tridactylus $=$ variegatus $)$ were extremely sensitive to the exogenously administered catecholamines. Other research $(19,24)$ suggested that the unanesthetized sloth has a mean arterial blood pressure of $129 / 86 \mathrm{mmHg}$, i.e., within the human range and not significantly greater than those seen in relaxed unanesthetized laboratory animals. However, handling and the mere approach of a person produced a rise in the sloth's blood pressure (Figure 2A) and in other cases a hypotensive bout (Figure 2B), suggesting an extreme lability in the control of blood pressure in this animal (25). Investigations to evaluate the role of pressoreceptors in awake sloths were carried out by Lima et al. (26), who analyzed the increase in blood pressure consequent to clamping of the carotid arteries. The increase in blood pressure was slow in onset and was not pronounced. After removal of the occlusion, the increase continued for some time. The authors suggested the possible participation of hormones during the ischemic period. Further research would be interesting in this field.

\section{Anesthesia and sedation}

It has been shown (27) that Choloepus hoffmanni and Choloepus didactylus can be immobilized by the intramuscular administration of Sernylan (phencylidine hydrochloride) at $1.65 \mathrm{mg} / \mathrm{kg}$ in combination with promazine hydrochloride at $0.85 \mathrm{mg} / \mathrm{kg}$. As the drugs take effect, there is a relaxation of the forelimbs accompanied by a loss of coordination and of the grasping reflex; similar changes in the hindlimbs follow shortly thereafter. Total immobilization is reached with a relaxation of the head and neck and partial relaxation of the jaw. Within 7 min the sloths
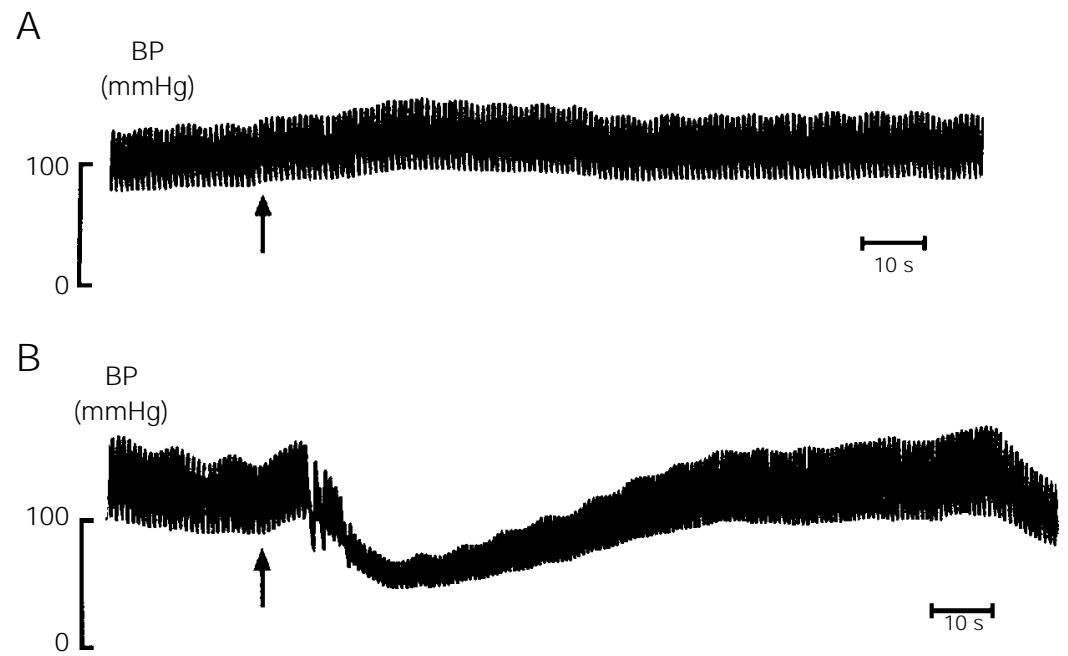

Figure 2 - Changes in arterial blood pressure (BP) in Bradypus variegatus in response to the approach of a human. A, A slight rise and $B$, a fall. 
can be safely handled and by $21 \mathrm{~min}$ immobilization is complete. No decrease occurs in the pupillary reflex nor are there any apparent changes observed in the eye reflexes. Although recovery times vary, by $5 \mathrm{~h}$ normal behavior returns and no undesirable side effects have been noted. Abdominal surgery on captive adult two-toed sloths (Choloepus $\mathrm{sp}$ ) has also been carried out using $50 \mathrm{mg}$ of ketamine hydrochloride given intramuscularly (28). Maned sloths (Bradypus torquatus) have been tranquilized by employing a mixture of ketamine $(1.3 \mathrm{mg} / \mathrm{kg})$ and acepromazine $(0.1 \mathrm{mg} / \mathrm{kg})$ so that external examinations could be carried out and blood collected (29). Two-toed sloths have been sedated with ketamine hydrochloride alone (2$6 \mathrm{mg} / \mathrm{kg}$ ) for the collection of blood (30) and a combination of tiletamine hydrochloride and zolazepam at a dose of $1.9-6.0 \mathrm{mg} / \mathrm{kg}$ has been employed to anesthetize these animals before obtaining blood from the femoral artery (8). Anesthesia induction times varied from 2 to $19 \mathrm{~min}$, with anesthesia lasting between 12 and $40.5 \mathrm{~min}$. Recovery times ranged from 2 to $6 \mathrm{~h}$.

Recently a comprehensive review (31) has been published comparing the effectiveness of different injectable anesthetic combinations given intramuscularly to 202 sloths (Choloepus didactylus). With acepromazine $(0.1 \mathrm{mg} / \mathrm{kg})$ given along with ketamine $(10$ $\mathrm{mg} / \mathrm{kg}$ ) the animals were quickly immobilized (within $2.5 \pm 2.0 \mathrm{~min}$ ), but the level of anesthesia induced and the muscle relaxation were both poor. Deep anesthesia within $1.8 \pm 0.6$ min with good muscle relaxation was also obtained by this group when using tiletamine/zolazepam $(10 \mathrm{mg} / \mathrm{kg})$, but irregular respiration and low relative oxyhemoglobin saturation values were often observed in the anesthetized sloths. Ketamine, when combined with the $\alpha_{2}$ agonists xylazine or medetomidine, was found to be the most suitable anesthetic providing good to excellent muscle relaxation, good analgesia, high oxyhemoglobin saturation values, and moderate bradycardia, although strong bradypnea was sometimes seen in association with medetomidine. Anesthesia occurred within $2.7 \pm$ 1.7 min when ketamine and xylazine were administered and within $2.5 \pm 5$ min when ketamine was injected along with medetomidine. The doses of the different drugs administered were $10 \mathrm{mg} / \mathrm{kg}$ of ketamine with 1 $\mathrm{mg} / \mathrm{kg}$ of xylazine and $3 \mathrm{mg} / \mathrm{kg}$ of ketamine with $0.04 \mathrm{mg} / \mathrm{kg}$ of medetomidine. The anesthesia induced with the combination of ketamine and medetomidine was reversed after $41.6 \mathrm{~min}$ by the intramuscular administration of atipamezole $(0.2 \mathrm{mg} / \mathrm{kg})$ and within $10.0 \pm 7.9 \mathrm{~min}$ the sloths were able to attain their normal hanging position. Intravenous injection of atipamezole shortened the recovery period. Following administration of the other three anesthetic combinations, the first signs of arousal were seen between 43 and $51 \mathrm{~min}$. Animals recovered calmly from the ketamine/xylazine combination and were able to support themselves after $34 \mathrm{~min}$ through grasping with at least two limbs. On the other hand, with the tiletamine/zolazepam-induced anesthesia, recovery was long and irregular averaging $76.7 \pm 31.3 \mathrm{~min}$; it was $3 \mathrm{~h}$ before some sloths were able to hang normally.

\section{Blood chemistry}

A brief review of the blood chemistry of the sloth was provided by Goffart (1). Since that time some further short papers have appeared which have shed further light on the sloths' hematological characteristics. An examination of blood samples taken from four specimens of Choloepus hoffmanni and one of Bradypus tridactylus showed that cholesterol levels were high and blood urea levels slightly so (32). Glucose levels were low in some of the animals despite an adequate diet. Serum albumin levels were low, but those of globulin high. In another investigation (8) the hematocrit measured in five male and two female two-toed sloths 
(Choloepus didactylus) averaged $43 \%$ (range $30-55 \%$ ) and the hemoglobin varied from 10.7 to $17.8 \mathrm{~g} / 100 \mathrm{ml}$ (mean $15.3 \mathrm{~g} / 100 \mathrm{ml}$ ). Red blood cells ranged from 2.1 to $3.5 \times 10^{6} /$ $\mathrm{mm}^{3}$ (mean $2.8 \times 10^{6} / \mathrm{mm}^{3}$ ) and white blood cells from 9.9 to $33 \times 10^{3} / \mathrm{mm}^{3}$ (mean 19.33 $\left.\mathrm{x} 10^{3} / \mathrm{mm}^{3}\right)$. The differential counts were found to be: basophils 1-3\%, eosinophils 1 $6 \%$, segmented neutrophils 5-42\%, lymphocytes $16-87 \%$ (mean $73 \%$ ) and monocytes 1 $4 \%$. Mean corpuscular volume was $151 \mathrm{~m}^{3}$, mean corpuscular hemoglobin $55 \mathrm{pg}$ and mean corpuscular hemoglobin concentration $36 \%$.

Meritt (6) collected blood from four twotoed sloths (Choloepus hoffmanni). Hemoglobin values were 11.7, 13.6, 13.6 and 13.6 $\mathrm{g} / 100 \mathrm{ml}$ and the mean hematocrit was $35 \%$. Red blood cells ranged from 3.85 to $5.04 \mathrm{x}$ $10^{6} / \mathrm{mm}^{3}$ and white blood cells varied from 13.4 to $21 \times 10^{3} / \mathrm{mm}^{3}$. The differential counts for the white blood cells as a percentage of the total present were: basophils 1 to 3 , eosinophils 0 to 5 , myelocytes 0 , juveniles 0 , stab cells 0 to 3 , segmented neutrophils 40 to 49 , lymphocytes 40 to 49 and monocytes 0 to 3 . These values fell within the range of variability of previous reports. Studies (33) on blood from four sloths (Bradypus variegatus) showed hemoglobin values of $11.06 \pm 0.45$ $\mathrm{g} / 100 \mathrm{ml}$, a hematocrit of $34.2 \pm 1.42 \%$, a mean corpuscular volume of $83.02 \pm 0.05$ $\mu \mathrm{m}^{3}$, a mean corpuscular hemoglobin of $27.16 \pm 1.89 \mathrm{pg}$ and a mean corpuscular hemoglobin concentration of $32.44 \pm 0.76 \%$. Red blood cells averaged $4.11 \pm 0.29 \times 10^{6} /$ $\mathrm{mm}^{3}$ blood while white blood cells were $12.46 \pm 1.02 \times 10^{3} / \mathrm{mm}^{3}$. Differential counts were $34.8 \pm 3.85 \%$ and typical lymphocytes were $56.4 \pm 3.44$. No basophils were found.

Recently a very detailed account (30) has been given of the hematology and serum chemistry profiles of captive two-toed sloths (Choloepus hoffmanni) and a comparison was made with the values obtained between juvenile ( $<3$ years) and adult ( $>3$ years) animals and between the sexes. The study took place in Burnet Park Zoo, Syracuse, New York, and involved a colony of animals originating from Panama. Blood samples were collected from sloths ranging in age from one to over 16 years. A total of 15 hematological and 24 biochemical parameters were evaluated and blood smears from five sloths of each sex were also examined for erythrocyte and leucocyte cell description and interpretation. Detailed results of these examinations were tabulated. Only serum alkaline phosphatase and cholesterol appeared to be affected by gender and age. Alkaline phosphatase was significantly elevated in juvenile females in comparison to values recorded in adult females and cholesterol levels were marginally higher in juvenile females in comparison to those recorded in juvenile males and adult females. Cholesterol values ranged widely, possibly reflecting a variation in diet. Mean sodium and chloride values recorded of 126 and 89.7 $\mathrm{mEq} / 1$, respectively, were slightly lower than those seen in domesticated species. Potassium levels averaged $5.8 \mathrm{mEq} / 1$. Mean serum chemistry values were as follows: glucose, $61 \mathrm{mg} / \mathrm{dl}$; urea nitrogen, $16.7 \mathrm{mg} / \mathrm{dl}$; creatine, $0.9 \mathrm{mg} / \mathrm{dl}$; uric acid, $2.9 \mathrm{mg} / \mathrm{dl}$; calcium, $9.3 \mathrm{mg} / \mathrm{dl}$; phosphorus, $4.6 \mathrm{mg} / \mathrm{dl}$; triglycerides, $114.8 \mathrm{mg} / \mathrm{dl}$; cholesterol, $194 \mathrm{mg} / \mathrm{dl}$. The total protein content was $7.5 \mathrm{~g} / \mathrm{dl}$ (albumin 3.9 and globulin 3.6) and total bilirubin $0.28 \mathrm{mg} / \mathrm{dl}$. Previous ranges for hematology and serum chemistry in the two-toed sloth were based on much lower sample numbers, with consequent considerable variations. These values (30) should stand as an excellent reference for future studies in this field.

Blood volume and iron kinetics were examined in three specimens of Bradypus tridactylus $=$ variegatus collected near Recife in Pernambuco (34). The hematocrit and hemoglobin values $(37 \%$ and $9.6 \mathrm{~g} / 100 \mathrm{ml}$, respectively) largely agreed with those of earlier studies reported by Goffart (1). The average plasma volume $(35.4 \mathrm{ml} / \mathrm{kg}$ body weight), as calculated by extrapolation of 
the plasma iron disappearance curve, was lower than that observed in humans, rats and dogs, as also were the calculated blood and red cell volumes ( 54.9 and $19.5 \mathrm{ml} / \mathrm{kg}$ body weight). However, in the sloth it is perhaps misleading to compare blood volume data to body weight as the latter can vary enormously depending on the amount of urine and feces retained. It was suggested (34) that, in retrospect, it might have been better to have correlated the values with lean body mass rather than body weight. The average iron disappearance half-time was found to be $150.6 \mathrm{~min}$ - approximately twice as long as in man, rat and dog. The mean iron uptake by erythrocytes was slightly less than that observed in man. Iron turnover rate was calculated to be $165.6 \mu \mathrm{g} \mathrm{kg}^{-1}$ day $^{-1}$ and red cell iron turnover rate $102.7 \mu \mathrm{g} \mathrm{kg}^{-1}$ day $^{-1}$.

Kleinschmidt et al. (35) examined the primary structure of hemoglobin collected from Bradypus tridactylus. They used chromatography on carboxymethyl cellulose CM52 to separate two components, an $\alpha$ - and a $\beta$-chain at the ratio of $4: 1$. Also reported were the amino acid sequences and compositions for the $\alpha$ - and $\beta$-chains. When the structures were compared with the corresponding human chains it was noted that there were 27 (19.1\%) amino acid replacements in the $\alpha$-chain and $33(22.6 \%)$ in the $\beta$ chain, necessitating at least 32 and 41 base substitutions in the respective genes. The replacements were distributed more or less randomly along the entire length of both chains, but the number of substitutions at functionally important positions was much larger in the $\beta$-chain. Whereas only one $\alpha_{1} / \beta_{1}$ contact was exchanged in the $\alpha$-chain, there were four replacements in the $\alpha_{1} / \beta_{1}$ subunit interface in the $\beta$-chain. When the hemoglobin from Bradypus tridactylus was compared with that from the armadillo (Dasypus novemcinctus) it was found that there were 25 and 34 replacements in the $\alpha$ - and $\beta$ chains, respectively. As there were also 25 and 32 exchanges between armadillos and humans, the suggestion was made (35) that there exists a similar period of divergent evolution between man and both Xenarthra on the one hand and sloth and armadillo on the other.

An examination (36) of the hemostatic profiles in five specimens of Bradypus variegatus found clotting time to be $6 \min 21$ $\pm 64 \mathrm{~s}$, partial activated thromboplastin time $45.5 \pm 8.52 \mathrm{~s}$ and prothrombin time $7 \mathrm{~min} 2$ \pm 39 s. Platelets numbered $324 \pm 24 \times 10^{3 /}$ $\mathrm{mm}^{3}$. Bleeding time was $1 \min 9 \pm 42 \mathrm{~s}$. Animals which had a higher platelet count showed a shorter bleeding time.

Blood gases measured (8) at $37^{\circ} \mathrm{C}$ in anesthetized two-toed sloths (Choloepus didactylus) were as follows: $\mathrm{pCO}_{2} 33.2 \pm$ $2.0, \mathrm{pO}_{2} 89.9 \pm 18.8$. The $\mathrm{pH}$ was $7.40 \pm$ 0.03 .

\section{Brain and spinal cord}

Goffart (1) gave only a brief account of the structure of the sloth brain, but he made reference to numerous anatomical studies carried out mainly in the nineteenth century. He did record, however, that the weight of the brain averaged $28.5 \mathrm{~g}$ in Choloepus hoffmanni and pointed out that the cerebral hemispheres do not extend over the cerebellum, but that the corpus callosum is well developed. Saraiva and Magalhães-Castro (37) reported on sensory and motor representation in the cerebral cortex of Bradypus. As might be expected, the area of the cortex devoted to the representation of the forelimb and especially the forepaw was considerably larger than that for the remaining body parts. The cortical area for the forelimb was followed in decreasing order of magnitude by the projections of the hindlimb, trunk and face. Visual and auditory projections occupied restricted areas on the caudal dorsolateral surface of the neocortex.

The anterior lobe of the cerebellum exerts a powerful tonic inhibitory influence over brain stem mechanisms affecting pos- 
ture and tone and its removal in the cat and dog results in a marked lack of coordination. This is followed by a phase of stabilized deficit during which significant compensation takes place (38). Raccoons are seen to compensate more rapidly after removal of this region of the brain than do cats and dogs. Murphy and O'Leary (38) examined hanging and climbing functions in both two- and three-toed sloths (Choloepus hoffmanni and Bradypus tridactylus) after cerebellectomy and compared these with the situation in the raccoon and cat. Attempts were made to follow changes in muscle tone in the sloths, which survived between six and eight days postoperatively, by passive manipulation of the limbs and from observations of arboreal behavior. Interestingly, cerebellectomy had no appreciable effect on the animals' ability to cope with the hanging and climbing requirements of their arboreal environment. If a rod was used to stimulate the foot pads of a clinging cerebellectomized sloth, a slowly developing powerful increase in the flexor tone of the limb caused the claws to grasp the rod so tightly that another was required to pry them loose. Interestingly, not a single clinging or hanging position was seen that was different between unoperated animals and those which had been cerebellectomized. This led to the suggestion (38) that, because sloths move with incredible slowness, minimal equilibratory and altitudinal controls are required to accomplish this. Thus one does not see the effects of cerebellectomy that is apparent, for example, in carnivores where, following the operation, oscillatory head and body tremor and truncal ataxia take place.

A detailed survey was carried out by Yaksh et al. (39) on the longitudinal and dorsoventral distribution of a variety of peptides in the spinal cord of five mammals including the two-toed sloth (Choloepus didactylus). Levels of substance $\mathrm{P}$, vasoactive intestinal polypeptide (VIP), cholecystokinin, neurotensin, met-enkephalin, bombesin and peptide-histidine-isoleucine (PHI) were measured using specific radioimmunoassays and reverse phase high performance liquid chromatography. Concentrations (ng/g) of the above peptides were tabulated in the dorsal and ventral horns and the dorsal root ganglion as a function of the level of the spinal cord in three-toed sloths and were compared with the values recorded in the cat, dog, owl-monkey and rhesus monkey. The findings emphasized a prominent and heterogeneous distribution of peptides throughout the rostrocaudal and dorsoventral regions of the spinal cord. With few exceptions, higher levels of peptides were present in the dorsal than in the ventral horn and all levels (but especially those of VIP and PHI) were elevated in the sacral cord compared to those in the more rostral segments.

\section{Vision}

It has been claimed that visual acuity is a requirement for successful adaptation to life in the forest canopy. However, sloths manage to survive extremely well despite possessing only relatively poor eyesight. Numerous experiments, summarized by Goffart (1), indicate that both Bradypus and Choloepus are extremely short-sighted and rely on additional senses for obtaining food, making contact with other members of their species and avoiding danger. Goffart concluded that the absence of a ciliary muscle and thus of the ability to accommodate, a pseudoangiotic retina, the lack of a macula and only sparse ganglion cells and nerve fibers indicate a low level of visual acuity and visual discrimination.

Since Goffart's review some valuable additional work has been carried out on vision in sloths (40-42). Using retinoscopy, an examination was made (40) of the ocular refraction of each eye in one male and seven female sloths (Bradypus tridactylus) collected near Manaus, and in a juvenile semidomesticated female. Ophthalmoscopy was 
also carried out on some sloths to determine pupil size and shape, to examine the fundus and to estimate the size of the visual fields and positions of the optic axes. Finally, the eyes of two sloths were examined histologically. The findings generally confirmed earlier studies on Choloepus hoffmanni discussed by Goffart (1), and suggest that sloths possess eyes that are primarily adapted for vision at low light intensities. It was reported (40) that the eyes of Bradypus are some 30 $\mathrm{mm}$ apart and are relatively frontal-looking, being of moderate size and having a wide and convex cornea. The angle between the diverging optic axes of each eye was estimated to be $50^{\circ}$ and the horizontal monocular and binocular visual fields were calculated to be $70^{\circ}$ with a binocular overlap at $35^{\circ}$. These latter measurements were made on two sloths whose pupils had been somewhat dilated with a cycloplegic drug. A wide variation in refractive error was observed in

Figure 3 - Distribution of ganglion cell densities in the right retina of a three-toed sloth Bradypus variegatus (A) and of a two-toed sloth Choloepus didactylus (B). Numbers next to each isodensity line represent cells/ $\mathrm{mm}^{2}$ divided by 1000 . The cross marks the position of the optic disc. Note the different position of the region of maximum cell density (area centralis) between the sloth species. In both instances the presence of a visual streak in the retina is indicated by the elongated contours of the isodensity lines representing intermediate densities around the area centralis, this being $0.8 \mathrm{x}$ $10^{3}$ in Bradypus variegatus and $0.4 \times 10^{3}$ in Choloepus didactylus.
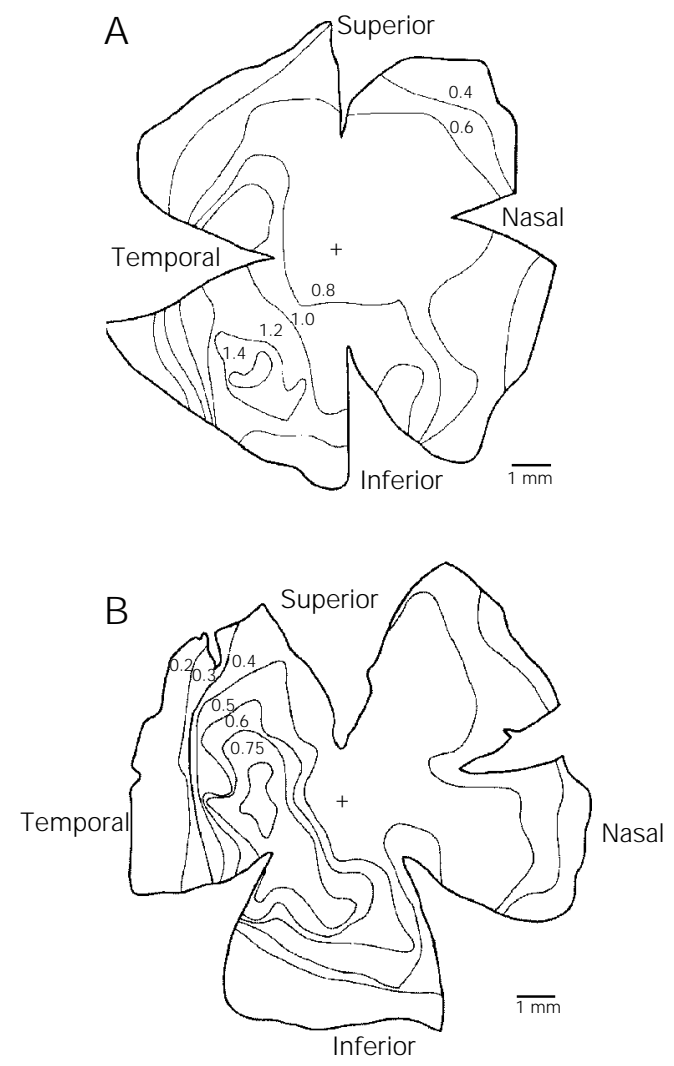

the nine sloths; three had marked hyperopia, two low hyperopia, two emmetropia and two marked hyperopic astigmatism. Anatomically the eye of Bradypus tridactylus was found to be nearly circular in an anterior-posterior section with overall dimensions of $8.4 \mathrm{~mm}$ axially and $8.3 \mathrm{~mm}$ equatorially. The cornea was found to be quite convex and uniformly thin and wide. The radius of the thick rounded crystalline lens was $2.35 \mathrm{~mm}$ in its anterior surface and $1.84 \mathrm{~mm}$ in its posterior surface. The equatorial:axial length ratio was found to be 1.36 compared to 1.7 reported for Choloepus hoffmanni by Goffart (1). It was suggested (40) that because of this higher ratio the lens of Choloepus is probably less optically powerful than that of Bradypus. Furthermore, the lens is not as thick and also appears to be less round. Finally, it was concluded (40) that the retinal histology of Bradypus is similar to that reported for Choloepus by Goffart (1), i.e., many slender rods with few ganglion cells are present and cones are rare or absent.

Andrade-da-Costa et al. $(41,42)$ examined in detail retinal wholemounts of both two- and three-toed sloths (Choloepus hoffmanni and Bradypus variegatus) for a quantitative analysis of the topographic distribution and size of the retinal ganglion cells using horseradish peroxidase (see Figures 3 and 4). In the three-toed sloth (41), ganglion cell density was found to gradually increase from about 500 cells $/ \mathrm{mm}^{2}$ at the periphery to a peak of around 1700 cells/ $\mathrm{mm}^{2}$ in a region deep in the inferior temporal retina localized within a range of $4.3 \pm 0.53$ $\mathrm{mm}$ from the optic disc, which corresponds to about 40.56 degrees of visual angle considering a retinal magnification factor (RMF) of $0.106 \mathrm{~mm} /$ degree (Figure $3 \mathrm{~A}$ ). The region of maximum cell density (area centralis) constituted only a weak retinal specialization with a maximum resolution power estimated to be 2.18 cycles/degree of visual angle (Andrade-da-Costa BLS, unpublished observations). Retinal cell diameters (Figure 
$4 \mathrm{~A})$ ranged from 5 to $21 \mu \mathrm{m}$, with peaks at $11-12,13-14$ and 15-16 $\mu \mathrm{m}$. There was a higher frequency of the smaller cells in the area centralis than in the superior nasal retina and other areas where large cells predominated. At least three different cell populations were identified relative to the soma size (Figure 3A). The inferior nasal and superior temporal retinal areas contained intermediate cell densities in what was termed the "visual streak", and retinal cell size was also intermediate in comparison to the area centralis and superior nasal retina. The authors discussed the unusual position of the area centralis and visual streak in the sloth retina by the animal's ability to rotate its head $180^{\circ}$ while climbing upside down along horizontal branches (Figure 5a). This would enable the sloth, by obtaining an image upon the inferior temporal region, to clearly visualize the branch directly above its head for accurate claw placement.

In the two-toed sloth (42), ganglion cell density in the retina was found to increase approximately 10 -fold from about 100 cells/ $\mathrm{mm}^{2}$ at the periphery to a peak of about 1000 cells $/ \mathrm{mm}^{2}$ in a central region along the temporal horizontal meridian (Figure 3B). A low cell density in the area centralis would indicate that this constitutes a region of only weak specialization. Surrounding the area centralis a visual streak was identified. Its orientation was vertical, stretching from the upper to the lower quadrant of the temporal retina along the vertical meridian. Interestingly, no significant difference was found in the distribution of ganglion cell sizes throughout the retina of the two-toed sloth in contrast to the situation in the three-toed species (Figure 4B and C). The results would indicate that the cells in the area centralis of the two-toed sloth have a lower resolving power than those of the three-toed sloth. However, the much larger eye of the former would effectively increase its visual resolution. Considering an $\mathrm{RMF}=0.151 \mathrm{~mm} /$ degree $(\mathrm{N}$ $=3$ ), the highest cell density in the area centralis in Choloepus didactylus (1000 cells/ $\mathrm{mm}^{2}$ ) corresponds to a maximum resolution power estimated as 2.38 cycles per degree, which is similar to that obtained for Bradypus variegatus. Moreover, it was pointed out (42) that as the two-toed sloth does not rotate its head when climbing, the area centralis would then be in the appropriate part of the retina for visualising the branch above (Figure $5 b$ ). The organization of the retina may therefore be governed by the demands imposed by the animal's lifestyle and not necessarily by how closely species are related.

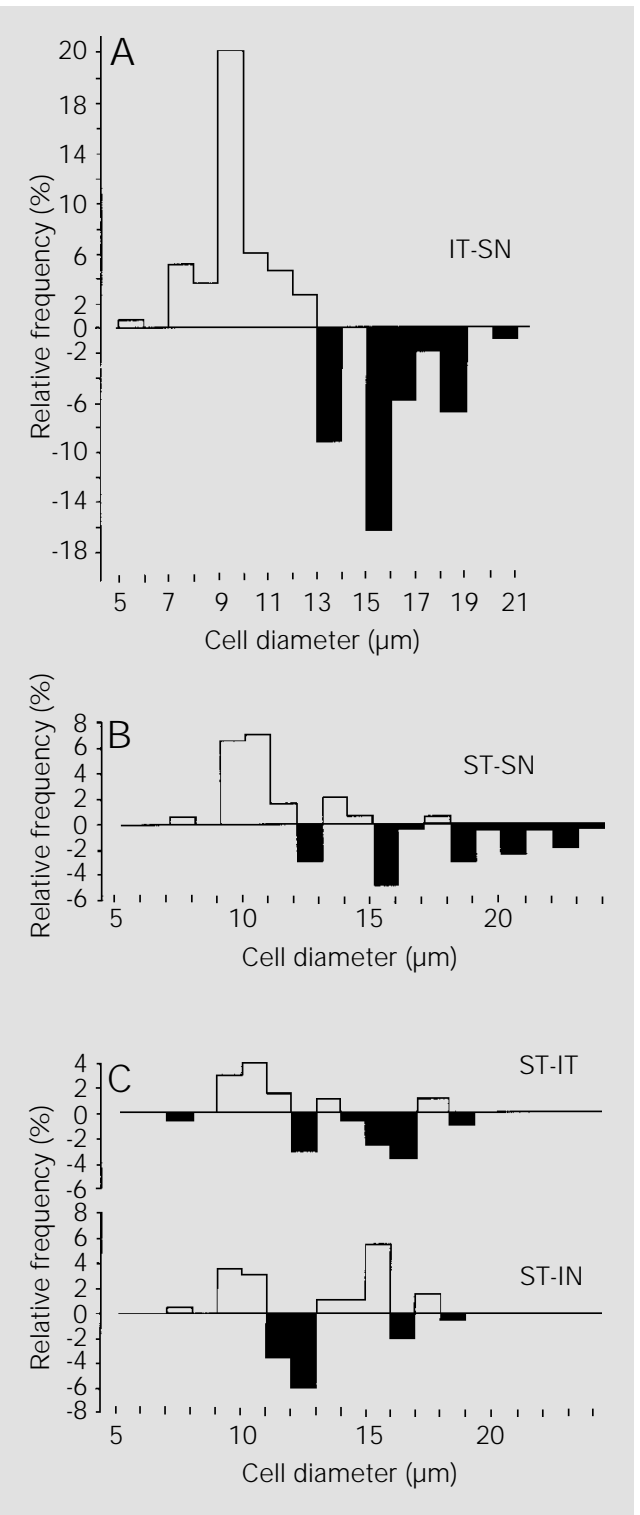

Figure 4 - Distribution of ganglion cell diameters in two different quadrants of the retina in Bradypus variegatus (A) and Choloepus didactylus (B). The relative frequency was obtained by subtracting the number of cells in the inferior temporal retina (IT) of the area centralis in Bradypus variegatus and in the superior temporal retina (ST) of Choloepus didactylus from the regions of lowest cell density in the superior nasal retina (SN) of both species. An excess of cells for each region of the area centralis over the nasal temporal retina is indicated by the portion of the histogram above the $0 \%$ line and the excess of cells for each region of the superior nasal retina over the inferior temporal retina is indicated by the portion of the histogram below the $0 \%$ line. $C$ is a histogram obtained by subtracting the relative frequency of cell diameters in the region of the area centralis (ST) of the retina in Choloepus didactylus from those in the IT and inferior nasal (IN) quadrants. 
Mendel et al. (43) studied activity in three adult female two-toed sloths using a time lapse video recorder. After one month the animals were fitted with a face mask, and following a period of adaptation, eye patches were added rendering the animals effectively blind, although still able to detect light. After a further seven days to allow habituation, the animals' behavior was recorded for another three weeks. Six months later additional studies on the sloths' behavior were carried out under simulated conditions of night and day. Retinoscopy was performed on another 11 two-toed sloths. Interestingly, the behavior of the animals when deprived of their sight did not differ significantly from the preced- ing situation, except that they spent less time outside. The retinoscopic investigation indicated that a majority of the 11 sloths were myopic, but some only slightly so. It would thus appear that the sloths rely little on vision to carry out their normal patterns of behavior.

\section{Sleeping and waking}

Of the two genera of living sloths, the genus Bradypus is the slower moving one with more quiescent behavioral patterns. Galvão de Moura Filho et al. (44) performed EEG recordings in Bradypus tridactylus = variegatus to study their correlation with
Figure 5 - $a$, Typical sequence of locomotion of Bradypus variegatus along a branch inclined at approximately $30^{\circ}(\mathrm{A}-\mathrm{F})$ and along another in the horizontal position (G-K). (Reproduced with permission from Mendel, 56). b, Typical sequence of locomotion of Choloepus hoffmanni along a branch inclined approximately $30^{\circ}$ in relation to the horizontal. (Reproduced with permission from Mendel, 57).
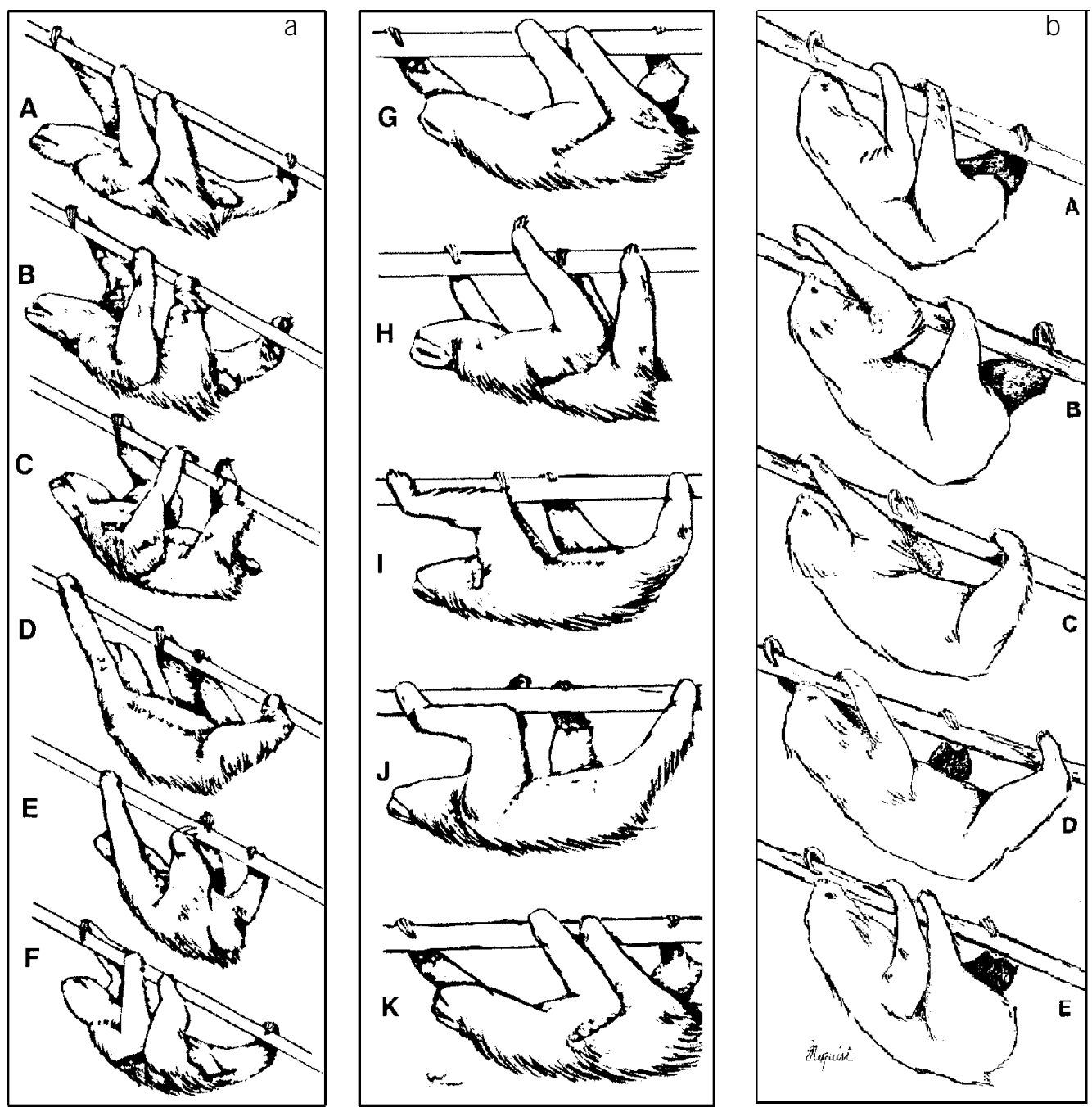
observed behavior. Behavioral patterns were divided into awake-exploring, awake-fixating, awake-alert and behavioral sleep. Sloths were found to show one or another type of waking behavior during $30.6 \%$ of the time and behavioral sleep during the remaining time. EEG recordings were classified as A1 (seen during awake-exploring and awakealert behavior), A2 (recorded when the animals were awake, but relaxed and drowsy), S1 and S2 (light sleep), S3 and S4 (deep sleep), and S5 (paradoxical sleep). Waking EEGs of various types were seen $34 \%$ of the time, about $10 \%$ of this during behavioral sleep. EEG patterns of light sleep constituted about $56 \%$ of the records made (about $6 \%$ during some form of waking behavior) and EEG patterns of deep sleep constituted about $10 \%$ of the recordings; all were made during behavioral sleep. Paradoxical sleep occupied $11 \%$ of the total sleep time. The different EEG patterns were nicely illustrated and analyzed and are comparable to those seen in other mammals (44). Although there was a lack of a well-developed relatively pure high amplitude alpha rhythm, this deficiency is also present in most mammals other than primates. Low voltage activity was seen in this frequency range, mixed with other frequencies during $\mathrm{A} 2$ and $\mathrm{S} 1$. True K-complexes were also lacking, although vertex sharp waves were prominent in S2 and S3. The sleep spindles (6-7/s) seen in the sloth were of a lower frequency than in the human, cat, guinea pig and opossum, although only slightly lower than those recorded in several species of rodents. Body temperature did not influence the frequency of the sleep spindles.

\section{Water balance and kidney function}

Goffart (1) described in detail the anatomy of the sloth kidney and discussed its concentrating ability. He also pointed out how Choloepus usually obtains its water requirements from the leaves, fruits and vegetables it eats, but in contrast it has been reported by others that, at least in captivity, sloths do drink appreciably. Nagy and Montgomery (45) measured carbon dioxide production and water flux using doubly labeled water in sloths (Bradypus variegatus) living on Barro Colorado Island. The animals comprized three adult females (two of them carrying young) and two adult males. The two young initially weighed $613 \mathrm{~g}$ and $460 \mathrm{~g}$. They found that water influx and efflux rates were almost equal, averaging around $39 \mathrm{ml} \mathrm{kg}^{-1}$ day $^{-1}$ and being approximately only half of those measured in laboratory animals. Water intake in the milk by young sloths varied during different measurement periods, averaging $15 \mathrm{ml} \mathrm{kg}^{-1}$ day $^{-1}$. Interestingly, the larger young consumed milk at a significantly lower rate than the smaller one, possibly because of supplementation of its diet with leaves. It was found that the two lactating sloths allocated about $5 \%$ of their water intake and $11 \%$ of their energy intake to milk production. Water production during oxidation of food in the sloths was estimated to be $4.2 \mathrm{ml}$ per day, leaving a daily deficit of over $34 \mathrm{ml}$. It appeared that the remaining water input came from the ingested leaves rather than from the drinking of rain water. It has been found (6) that the average daily water consumption of Choloepus hoffmanni in captivity was $170 \mathrm{ml}$ per animal, with measured amounts of excreted urine averaging $808 \mathrm{ml}$ (ranging from 340 to $1600 \mathrm{ml}$ ). It was also observed (6) that urine (deposited at the same time as the feces) was clear and yellow to brown and had a specific gravity of 1.023. It was reported earlier (46) that the urine of the two-toed sloth has a specific gravity ranging from 1.020 to 1.031 and a $\mathrm{pH}$ ranging from 7.0 to 9.0 .

Rappaport and Hochman (28) reported on the occurrence of cystic calculi in captive two-toed sloths. A male presented with a rectal prolapse which was repaired, but later recurred. At surgery the bladder was found to be greatly thickened and inflamed with 
several stones palpable in the lumen. Upon examination these were found to be composed of calcium, magnesium, ammonium and phosphorus. Some months later a large stone measuring $7-8 \mathrm{~cm}$ in diameter was removed from the bladder of a female sloth that was experiencing trouble when urinating and defecating. Both sloths recovered well and it was speculated that the stones were a result of the sloths' diet which consisted of a mixture of fresh fruit and vegetables along with a protein supplement.

\section{Reproduction}

A brief update of the reproductive and endocrine systems of the sloth summarizing recent studies in these fields was provided by Gilmore and Da Costa (47). Although the anatomy of the reproductive organs of the sloth has been extensively investigated (see 1), there is still much to be learned about the reproductive physiology and breeding of sloths, especially Bradypus. Little indeed is known about courtship and mating in Bradypus, which was reported to be direct and brief $(1,48,49)$. Richard-Hansen and Tauber (49) described a series of copulations between a female three-toed sloth (Bradypus tridactylus), carrying a young estimated to be three to four months old, and a male which had been sharing the same tree since the previous day. Most of the initiative came from the male, who approached the female, and face to face copulation lasting around 3 min took place. During this time the male was secured by his forelimbs while holding the female, which was hanging from a branch, with his hindlegs. Five minutes later mating occurred again, but this time with the male on the female's back. This copulation was interrupted by the female which withdrew after $2 \mathrm{~min}$. However, the male followed her and eventually they mated again face to face for one and a half minutes. Throughout the whole 25-min period, from initial approach to final separation when the male descended and left the tree, the juvenile remained attached to its mother's abdomen. In contrast to the situation in Bradypus, Meritt (6) has provided a lot of detail about Choloepus hoffmanni, having studied captive animals in a Chicago zoo between 1968 and 1977 and undertaken field work in Panama. He reported that in this two-toed sloth females in estrus appear to actively initiate mating.

Interbirth interval and gestation length are also not well known for three-toed sloths and there is still some disagreement as to whether there is a breeding season for Bradypus, or whether the animals reproduce throughout the year. Births in Bradypus variegatus have been recorded on the outskirts of Recife in August and November (see 1,47). Recently, 226 female three-toed sloths (Bradypus tridactylus) were captured and examined by Richard-Hansen and Tauber (49) over a 16-month period during the filling of the Petit-Saut dam in Guyane. They observed that young were carried from April to September 1994 and pregnancies were recorded from March through September 1994 and from January 1995. However, it has also been stated (29) that breeding in Bradypus torquatus is not seasonal. Newborn individuals were captured along with their mothers in July and two juveniles near weaning in August and December; another juvenile of intermediate weight was captured in November. In Choloepus didactylus, births in captivity at the Smithsonian Institution (Washington) were recorded every month except April, September and November (50).

Beebe (51) estimated gestation in Bradypus tridactylus to last between four and six months, and Tirler (52) reported it to be between five and six months in Bradypus variegatus with a one-year interval between births. Studies on Bradypus variegatus (53) have indicated that the females give birth in successive years. Pregnancy in Choloepus didactylus has been estimated (54) to equal or exceed 10.5 months with a 26-month 
interval between births if the young survived, but only 14 months if the newborn died. Goffart (1) reported that birth of the single young, weighing 230-250 g, takes place on the ground or in the hanging position. McCrane (50) described a birth in captivity of Choloepus didactylus. The mother was in an upside down hanging position and made attempts with one forelimb to pull the infant between her hind legs and on to the abdomen. Although approximately $20 \mathrm{~cm}$ of umbilical cord was exposed, no blood of any consequence was observed. Other sloths were seen preventing the infant from falling and cleaning both it and the mother by licking.

Work in Costa Rica (55) on Bradypus tridactylus $=$ variegatus has suggested that males are fertile throughout the year. Two animals killed during the rainy season in July and two during the dry season in December all displayed normal spermatogenesis, with the seminiferous tubules showing a spermatogenic wave similar to that seen in rodents. However, more recent work in Pernambuco (48) has indicated that, although breeding may occur throughout the year, only a minority of male sloths (Bradypus variegatus) would appear to be sexually active at any one time.

Maturation in the sloth is a rather slow process. It has been stated (52) that the threetoed sloth may take up to six years to reach maturity. However, in contrast, it has also been reported (54) that although male specimens of Choloepus didactylus in captivity are not sexually mature till four and a half years, females will breed at three years. Meritt (6) reported a case of sexual maturity in a female two-toed sloth (Choloepus hoffmanni) at two years of age; this animal died when 30 months old, with a well-formed fetus in utero.

Estrus in the sloth is hard to detect. Two female sloths were observed (6) rubbing against one another in a near vent to vent position during the onset of estrus; there were, however, no changes in genital appearance or secretions. When in estrus a female was seen to attempt to solicit a male by pressing close in an attempt to rub her anogenital region against him. Interestingly, the male, though not aggressive, showed no real interest and exhibited no sexual behavior. Meritt (6) described "menstruation" in Choloepus hoffmanni with a small amount of blood being present on the external genitalia; edema of the vaginal lips was also noted. The "menstrual cycle" lasted 5 to 7 days. Days one to three were marked by the presence of rusty-colored fluid or blood in or on the vaginal opening. On day four the external genitalia were dry and clean, but slightly puffy. Genital edema was still present from days five to seven, but secretions were absent.

Parturition in the sloth is difficult to diagnose and observe, but Meritt (6) recorded a number of births in Choloepus hoffmanni that took place in the Chicago zoo. During the postpartum period, he noted a total absence of blood, blood-tinged fluids or tissue debris in or around the genitalia, which were not obviously torn or distended. The single offspring, weighing 350 to $454 \mathrm{~g}$, was always born during daylight hours and was alert and strong. The eyes were open, the ear pinnae patent, the teeth present, and the claws fully formed and hard. The gripping reflex was well developed in both front and hind feet, enabling the young to cling to or crawl about the mother's abdomen. The newborns were fully haired, except over the ventral surface, vocalized loudly and were capable of coordinated movement. Although no obvious breast development or milk flow was noticed prior to parturition, nuzzling and suckling by the newborn stimulated the release of milk, usually within the first $48 \mathrm{~h}$ (6). The mother was solicitous of the offspring and spent a considerable amount of time vigorously licking its head and face and cleaning the anogenital region, thus stimulating elimination. The urine and feces so produced were consumed by the mother. The newborns were nursed for periods of 6 
to $15 \mathrm{~min}$ at a time on several occasions each day. It was observed (6) that water was first consumed at seven days and food taken at 15 days by a male and at 27 days by a female. Play behavior was noted at 15 and 19 days of age. The young first assumed a hanging or upside down position between 20 and 25 days and solid food was actively sought between 30 and 42 days. The first apparent exploration away from the mother and in close proximity to other sloths was observed at 59 days in a female and at 65 days in a male. As time elapsed these exploratory periods would last longer and the distances away from the mother increase. If its return was blocked, the infant made loud and characteristic bleats lasting 30 to $90 \mathrm{~s}$ which induced the mother to respond. Sleeping in an adult position close to, but apart from the mother, was noted at 50 days for a female and at 65 days for a male. By 5 months the sloths were regularly feeding on solid food away from the mother and by 6 months were eliminating in typical adult fashion, but were still in behavioral association with the mother, and continued to be carried on the mother's abdomen till 8 months. There was no sudden or dramatic break in the tie between mother and offspring, rather there was a gradual change from maternal dependence to one of companionship and association as the young sloth matured. Even at two years of age a female offspring was most often found in close proximity to its mother, frequently being active and feeding or resting in her company.

\section{Acknowledgments}

We thank Professor B. Andrade Da Costa for assistance in the drafting of this manuscript.

\section{References}

1. Goffart M (1971). Function and Form in the Sloth. Pergamon Press, Oxford, New York, Toronto, Sydney, Braunschweig.

2. de J ong WW, Zweers A, J oysey KA, Gleaves J T \& Boulter D (1985). Protein sequence analysis applied to xenarthran and pholidote phylogeny. In: Montgomery GG (Editor), The Evolution and Ecology of Armadillos, Sloths, and Vermilinguas. Smithsonian Institution Press, Washington and London, 65-76.

3. Wetzel R (1985). The identification and distribution of recent Xenarthra (= Edentata). In: Montgomery GG (Editor), The Evolution and Ecology of Armadillos, Sloths and Vermilinguas. Smithsonian Institution Press, Washington and London, 5-21.

4. McNab BK (1985). Energetics, population biology, and distribution of Xenarthrans, living and extinct. In: Montgomery GG (Editor), The Evolution and Ecology of Armadillos, Sloths and Vermilinguas. Smithsonian Institution Press, Washington and London, 219-232.

5. Silva VL, Lucena RLBG, Silva EM, Viana FMM, Silva IGC, Oliveira J r WM, Sa VCT, Fernandes DN, Pinto AXM, Silva J r ED, Duarte DPF \& Da Costa CP (1996). Influéncia da temperatura ambiental sobre a temperatura corporal em preguiças Bradypus variegatus. XI Annual Meeting of the "Federação de Sociedades de Biologia Experimental", August 21-24, Caxambu, MG, Brazil, 225 (Abstract 34.026).

6. Meritt DA (1985). The two-toed sloth, Choloepus hoffmanni Peters. In: Montgomery GG (Editor), The Evolution and Ecology of Armadillos, Sloths and Vermilinguas. Smithsonian Institution Press, Washington and London, 333-341.

7. Britton SW (1941). Form and function in the sloth. Quarterly Review of Biology, 16: 13-34 and 190-207.

8. Bush M \& Gilroy BA (1979). A bleeding technique from nonpalpable vessels in anesthetized two-toed sloths (Choloepus didactylus) - plus hematologic data. J ournal of Zoo Animal Medicine, 10: 26-27.

9. Félix CH, Da Costa CP \& Zin WA (1987). Controle da ventilação em preguiças (Bradypus variegatus) anestesiadas.II Annual Meeting of the "Federação de Sociedades de Biologia Experimental", J uly 812, Rio de J aneiro, RJ , Brazil, 183 (Abstract 2.51).

10. Santos MSB, Santos AC, Alpes IM, Ribeiro ACC, De Lima AMJ, Bizerra VMSX, Silva EM, Silva VL, Duarte DPF \&
Da Costa CP (1998). Monitorização a longo prazo da freqüência respiratória em preguiças, Bradypus variegatus. XIII Annual Meeting of the "Federação de Sociedades de Biologia Experimental", August 26-29, Caxambu, MG, Brazil, 284 (Abstract 11.045).

11. Santos MSB, Santos AC, Alpes IM, Pinto AXM, Pereira CV, Bezerra LL, Pedrosa MAC, Duarte DPF \& Da Costa CP (1998). Padrão respiratório em preguiças (Bradypus variegatus) não anestesiadas. XIII Annual Meeting of the "Federação de Sociedades de Biologia Experimental" August 26-29, Caxambu, MG, Brazil, 384 (Abstract 11.077).

12. Aguiar FB, Félix $\mathrm{CH}$, Da Costa $\mathrm{CP} \&$ Zin WA (1988). Estudos dos volumes e capacidades pulmonares em preguiças (B. variegatus) anestesiadas. III Annual Meeting of the "Federação de Sociedades de Biologia Experimental", J une 29-J uly 3, Caxambu, MG, Brazil, 81 (Abstract 2.54).

13. Aguiar FB, Félix $\mathrm{CH}$, Da Costa $\mathrm{CP} \& \mathrm{Zin}$ WA (1988). Propriedades mecânicas ativas do sistema respiratório de preguiças (B. variegatus) anestesiadas. III Annual Meeting of the "Federação de Sociedades de Biologia Experimental", J une 29-J uly 3, Caxambu, MG, Brazil, 81 (Abstract 2.53). 
14. Félix CH, da Costa CP \& Zin WA (1988). Propriedades mecânicas passivas do pulmão e parede torácica em preguiças (B. variegatus) anestesiadas. III Annual Meeting of the "Federação de Sociedades de Biologia Experimental", J une 29-J uly 3, Caxambu, MG, Brazil, 82 (Abstract 2.56).

15. Oliveira LHA, Da Costa CP \& Huggins SE (1980). Cardiac mass, blood temperature and ventricular fibrillation: a study of the comparative physiology of the three-toed sloth and the domestic cat. Comparative Biochemistry and Physiology, 67A: 483490.

16. Cabral AMS, Da Costa CP \& Huggins SE (1980). Cardiac output in the three-toed sloth, Bradypus tridactylus. Comparative Biochemistry and Physiology, 67A: 527530.

17. Duarte DPF, Huggins SE, Da Costa CP \& Leal AM (1989). Responses of the threetoed sloth, Bradypus tridactylus, to some commonly used pharmacologic agents. II. Chloralose and reserpine. Comparative Biochemistry and Physiology, 92C: 405411.

18. Duarte DPF, Da Costa CP \& Huggins SE (1982). The effects of posture on blood pressure and heart rate in the three-toed sloth, Bradypus tridactylus. Comparative Biochemistry and Physiology, 73A: 697702.

19. Duarte DPF, Da Costa CP \& Huggins SE (1983). The autonomic component in blood pressure and heart rate effects of tilting in the three-toed sloth. Comparative Biochemistry and Physiology, 74C: 485-492

20. Silva EM (1996). Estudo do eletrocardiograma e do ritmo cardíaco na preguiça, Bradypus variegatus. Master's thesis, Universidade Federal de Pernambuco, Recife, PE, Brazil.

21. Valentinuzzi ME, Ruiz EDV \& Da Costa CP (1984). Ventricular fibrillation threshold in the three-toed sloth (Bradypus tridactylus). Acta Physiologica et Pharmacologica Latinoamericana, 34: 313-322.

22. Cingolani HE, Moita MM \& Da Costa CP (1979). Caracteristicas mecánicas del miocardio de perezoso (Bradypus tridactylus). Acta Physiologica Latinoamericana, 29: 67-70.

23. Duarte DPF, Huggins SE, Da Costa CP \& Leal AM (1987). Responses of the threetoed sloth, Bradypus tridactylus, to some commonly used pharmacologic agents. I. Autonomic drugs. Comparative Biochemistry and Physiology, 88C: 275-285.

24. Duarte DPF, Huggins SE, Da Costa CP \& Leal AM (1989). The effects of posture changes on blood pressure and heart rate of anaesthetized and reserpinized sloths. Comparative Biochemistry and Physiology, 94A: 159-165.

25. Duarte DF, Da-Costa CP \& Huggins SE (1986). Hypotensive bout in the sloth, Bradypus variegatus: A possible pattem of response to stress. Brazilian J ournal of Medical and Biological Research, 19: 519A (Abstract).

26. Lima WA, Levy R, Cabral AMS, Notereya MA, Duarte DPF \& Da Costa CP (1993). Estudo da resposta pressora obtida por oclusão das carótidas comuns em Bradypus variegatus acordada. VIII Annual Meeting of the "Federação de Sociedades de Biologia Experimental" , August 25-28, Caxambu, MG, Brazil, 89 (Abstract 2.81).

27. Meritt DA (1974). A further note on the immobilisation of sloths. International Zoo Yearbook, 14: 160-161.

28. Rappaport AB \& Hochman H (1988). Cystic calculi as a cause of recurrent rectal prolapse in a sloth (Choloepus sp.). J ournal of Zoo Animal Medicine, 19: 235-236.

29. Pinder $L$ (1993). Body measurements, karyotype, and birth frequencies of maned sloth (Bradypus torquatus). Mammalia, 57: 43-48.

30. Wallace C \& Oppenheim YC (1996). Hematology and serum chemistry profiles of captive Hoffmann's two-toed sloths (Choloepus hoffmanni). J ournal of Zoo and Wildlife Medicine, 27: 339-345.

31. Vogel I, de Thoisy B \& Vie J C (1998). Comparison of injectable anaesthetic combinations in free-ranging two-toed sloths in French Guiana. J ournal of Wildlife Diseases, 34: 555-566.

32. Toole J F (1972). Blood chemistry of the sloth (Choloepus hoffmanni and Bradypus tridactylus). Laboratory Animal Science, 22: 118-121.

33. Medeiros IRT, Vasconcelos $A E$, Silveira AP, Henriques FGOTB, Montenegro PFGP, Marcelino NA, Duarte DPF, Da Costa CP \& Cabral AMS (1993). Estudos hematológicos na preguiça (Bradypus variegatus). VIII Annual Meeting of the "Federação de Sociedades de Biologia Experimental", August 25-28, Caxambu, MG, Brazil, 268 (Abstract 13.53).

34. Bozzini CE, Henriques J AP \& Ladosky W (1978). Characterization of the blood volume and iron kinetics in the three-toed sloth, Bradypus tridactylus. Comparative Biochemistry and Physiology, 61A: 417418.

35. Kleinschmidt L, Marz J \& Braunitzer G (1989). The primary structure of palethroated three-toed sloth (Bradypus tri- dactylus, Xenarthra) hemoglobin. Biological Chemistry Hoppe-Seyler, 370: 303308.

36. Henriques FGOTB, Silveira AP, Vasconcelos AE, Medeiros IRT, Montenegro PFGP, Oliveira AA, Rodrigues AC, Cabral AMS, Duarte DPF \& Da Costa CP (1993). Determinação do perfil hemostático na preguiça, Bradypus variegatus. VIII Annual Meeting of the "Federação de Sociedades de Biologia Experimental", August 25-28, Caxambu, MG, Brazil, 267 (Abstract 13.52).

37. Saraiva PES \& Magalhães-Castro B (1975). Sensory and motor representation in the cerebral cortex of the three-toed sloth (Bradypus tridactylus). Brain Research, 90: 181-193.

38. Murphy MG \& O'Leary J L (1973). Hanging and climbing functions in racoon and sloth after total cerebellectomy. Archives of Neurology, 28: 111-117.

39. Yaksh TL, Michener SR, Bailey J E, Harty GJ , Lucas DL, Nelson DK, Roddy DR \& Go VLW (1988). Survey of distribution of substance $P$, vasoactive intestinal polypeptide, choleocystokinin, neurotensin, metenkaphalin and $\mathrm{PHI}$ in the spinal cord of cat, dog, sloth and monkey. Peptides, 9: 357-372.

40. Piggins D \& Muntz WRA (1985). The eye of the three-toed sloth. In: Montgomery GG (Editor), The Evolution and Ecology of Armadillos, Sloths and Vermilinguas. Smithsonian Institution Press, Washington and London, 191-197.

41. Andrade-da-Costa BLS, Pessoa VF, Bousfield J D \& Clarke RJ (1987). Unusual distribution of ganglion cells in the retina of the three-toed sloth (Bradypus variegatus). Brazilian J ournal of Medical and Biological Research, 20: 741-748.

42. Andrade-da-Costa BLS, Pessoa VF, Bousfield J D \& Clarke RJ (1989). Ganglion cell size and distribution in the retina of the two-toed sloth (Choloepus didactylus L.). Brazilian J ournal of Medical and Biological Research, 22: 233-236.

43. Mendel FC, Piggins D \& Fish DR (1985). Vision of two-toed sloths Choloepus. J ournal of Mammalogy, 66: 197-200.

44. Galvão de Moura Filho A, Huggins SE \& Lines SG (1983). Sleep and waking in the three-toed sloth, Bradypus tridactylus. Comparative Biochemistry and Physiology, 76A: 345-355.

45. Nagy KA \& M ontgomery GG (1980). Field metabolic rate, water flux, and food consumption in three-toed sloths (Bradypus variegatus). J ournal of Mammalogy, 61 : 465-472.

46. Meritt DA (1973). Edentate diets. II. Two- 
toed sloths. Laboratory Animal Science, 23: 543-545.

47. Gilmore DP \& Da Costa CP (1995). The three-toed sloth in biomedical research: an update on the endocrine and reproductive systems. Medical Science Research, 23: 579-581.

48. Gilmore DP, Da Costa CP, Cabral A, Duarte DPF, Montgomery I \& Wilson CA (1994). Further studies on reproductive function in the three-toed sloth, Bradypus tridactylus. Medical Science Research, 22: 255-256.

49. Richard-Hansen C \& Tauber E (1997). Note on the reproductive behavior of the three-toed sloth, Bradypus tridactylus, in French Guiana. Mammalia, 61: 259-263.

50. McCrane MP (1966). Birth, behaviour and development of a hand-reared two-toed sloth. International Zoo Handbook, 6: 153163.

51. Beebe W (1926). The three-toed sloth Bradypus cuculliger cuculliger Wagler. Zoologica, 7: 1-67.

52. Tirler H (1966). A Sloth in the Family. The Harvill Press, London.

53. Montgomery GG \& Sunquist ME (1978). Habitat selection and use by two-toed and three-toed sloths. In: Montgomery GG (Editor), Ecology of Arboreal Folivores. Smithsonian University Press, Washington, DC, 329-339.

54. Eisenberg J F \& Maliniak E (1985). Maintenance and reproduction of the two-toed sloth Choloepus didactylus in captivity. In: Montgomery GG (Editor), The Evolution and Ecology of Armadillos, Sloths and Vermilinguas. Smithsonian Institution Press, Washington and London, 327-346.

55. Toyama Y, Calderon FU \& Quesada R (1990). Ultrastructural study of crystalloids in Sertoli cells of the three-toed sloth (Bradypus tridactylus). Cell and Tissue Research, 259: 599-602.

56. Mendel FC (1985). Use of hands and feet of three-toed sloth (Bradypus variegatus) during climbing and terrestrial locomotion. J ournal of Mammalogy, 66: 359-366.

57. Mendel FC (1981). Use of hands and feet of two-toed sloths (Choloepus hoffmanni) during climbing and terrestrial locomotion. J ournal of Mammalogy, 62: 413-421. 